\title{
Power through Collaboration: Stakeholder Influence in EU Climate and Energy Negotiations
}

\author{
Inga Margrete Ydersbond \\ Department of Political Science, University of Oslo, PB 1097 Blindern, 0317 Oslo, \\ Norway \\ inga.ydersbond@stv.uio.noandimy@toi.no
}

Received 30 July 2017; accepted 19 November 2017

\begin{abstract}
Who gets what in high-level European Union (EU) negotiations and how? This study draws on data concerning stakeholder preferences during heated negotiations leading to the EU's 2030 Climate and Energy Policy Framework. It tests the explanatory values of Liberal Intergovernmentalism (LI), the Advocacy Coalition Framework (ACF), and Historical Institutionalism (HI). Large member states were key (LI). However, coordinated groups of member states, bound by specific common interests, also played crucial roles. ACF explains the 2030 Framework only if: a) the decisive coalitions consisted of the EU's supranational institutions, the coordinated groups of member states and long-term advocacy coalitions in the interest group community; b) coalition members held comparatively similar views; and c) coalition members adjusted their strategies mutually and/or shared information. The European Commission set the agenda (HI). The analysis demonstrates that LI, HI and ACF may be used as complementary analytical tools, filling several of each other's gaps.
\end{abstract}

\section{Keywords}

European Union - negotiations - climate and energy - interest groups - advocacy coalitions - theory testing - EU integration

* Inga Margrete Ydersbond conducted this study as part of her PhD thesis at the Department of Political Science at the University of Oslo. She is presently a researcher at the Institute of

(C) INGA MARGRETE YDERSBOND, 2018 | DOI:10.1163/15718069-23031161

This is an open access article distributed under the terms of the prevailing CC-BY-NC License 
Sabatier (1998: 121) claims that the widely applied Advocacy Coalition Framework (ACF) "offers a number of advantages for studying EU policy processes," but scant literature has tested ACF on EU cases. ${ }^{1}$ Therefore, testing the explanatory value of ACF in coordination with theories emphasizing other stakeholders and causal mechanisms, such as Liberal Intergovernmentalism (LI) (Moravcsik 1993, 1998) and Historical Institutionalism (HI) (Pierson 1996), should demonstrate the strengths and weaknesses of these different approaches and clarify their theoretical and empirical contributions.

The EU's framework for climate and energy policies from 2020 to 2030, the 2030 Climate and Energy Policy Framework (2030 Framework, for short), lends itself to such complementary theory testing as arguably a most-likely case of LI, HI and ACF. Stakeholders and mechanisms identified in the theoretical frameworks are all expected to play a major role. LI emphasizes the role of the EU member states, particularly the largest ones, including how key industries shape their political positions. Traditionally, energy policy has been a field with strong national legislative authority. The ACF focuses on coalitions of private and public stakeholders spanning several levels of government which conduct "political venue shopping." EU processes are well-suited to ACF analysis (Jenkins-Smith et al. 2014; Sabatier 1998). In fact, ACF has been applied most frequently to studies of climate and energy policies (Weible et al. 2009: 125-126). Finally, HI points towards underlying drivers of European integration. Path dependency, independent action of the EU's supranational institutions and unintended consequences contribute to transfer of legislative competence to the EU level. It is said that these theoretical perspectives should be subject to rigorous application and testing (Jenkins-Smith et al. 2014: 189; Moravcsik 1998: 17; Pierson 1996: 157-158) and assessed together with other theories (Jupille et al. 2003: 17, 21; Tallberg 2010: 644) to elucidate multi-causality. Therefore, this study asks: To what extent can LI, ACF and HI describe and explain the outcome of climate and energy negotiations in the EU, exemplified in the 2030 Climate and Energy Policy Framework?

Transport Economics in Oslo. She has published extensively on the EU's climate and energy policy, negotiations within this field, European integration, and renewable energy.

1 I am grateful for financial support from Ryoichi Sasakawa Young Leaders Fellowship Fund (Sylff) from The Tokyo Foundation for Policy Research, from Strategic Challenges in International Climate and Energy Policy (CICEP), the Department of Political Science at the University of Oslo and from UiO Energy for supporting my research stays in Brussels. I would like to thank Morten Egeberg, Frode Veggeland, Derek Beach, Anton Steen, Trond Arild Ydersbond, Tor Håkon Jackson Inderberg, Øivind Bratberg, Elin Lerum Boasson, Torbjørg Jevnaker, and an anonymous reviewer for helpful comments to the study. I also owe heartfelt thanks to Tanja Christensen for language editing. 
This study's first objective is to assess the merits of these theoretical perspectives in illuminating the EU system's power dynamics. The second objective is to better understand negotiations leading up to the 2030 Framework, for three reasons. First, although the 2030 Framework negotiations hold significant importance, few comprehensive analyses exist so far. Negotiations were strategically significant for the EU and its member states; ever since international negotiations leading up to the 1997 Kyoto agreement, the EU has sought to lead by example. To this end, the EU notified the United Nations (UN) of its own commitments in advance (2014) to set a precedent and motivate other participants before the December 2015 climate negotiations in Paris. Second, the 2030 Framework exemplifies the EU's climate and energy ambition for 2020-2030. It is an essential tool to achieving a sustainable energy transition at the lowest societal cost and reaching the EU target of reducing greenhouse gas emissions between $80 \%-95 \%$ by 2050 . Therefore, the 2030 Framework also suggests large-scale transformation of the member states' energy systems, with wide-ranging consequences for national authorities, domestic industries and citizens. Third, few studies have systematically investigated stakeholder influence on an EU climate and energy policy framework from a multi-stakeholder perspective which includes the EU's supranational institutions, all member states as well as a wide range of interest groups and other nongovernmental stakeholders. The EU's supranational institutions, member states and communities of interest groups were all engaged heavily at national and EU levels in the 2030 Framework negotiations. Negotiations themselves were particularly intense considering the high stakes and many controversial issues to be addressed. This makes the case analytically interesting, and potentially instructive in assessing stakeholder influence (Thomson 2011: 31-32).

\section{Theoretical Perspectives ${ }^{2}$}

\section{Liberal Intergovernmentalism}

Moravcsik's (1993) theory is often used to explain outcomes of large intergovernmental conferences (Pierson 1996: 130). However, Moravcsik and Schimmelfennig (2009: 74) underscore that LI is also applicable to everyday EU decision-making when legislation is agreed upon "by de facto consensus or unanimity, even when the formal rules seem to dictate otherwise," thus

2 In the supplemental material to this article, online at 10.6084/mg.figshare.6825899, Appendix 1 outlines the causal mechanisms in Liberal Intergovernmentalism, the Advocacy Coalition Framework and Historical Institutionalism. 
applying to a much wider range of EU decisions. When the 2030 Framework was decided at the Summit of the European Council in October 2014, member states agreed that voting would be based on unanimous decisions, creating an apt case for LI application.

LI rests on three basic premises: a) state behavior is rational; b) national governments are independent but constrained by the intensity of domestic group preferences (affected by the legislation under negotiation), and whether domestic groups are divided on the topic; and c) national governments negotiate with each other at the intergovernmental level. Hence, EU negotiations should be understood as two-level games with national governments as the key actors (Moravcsik 1993: 480-481). Governments may delegate some authority to supranational institutions such as the European Commission (hereafter, Commission), but only in order to achieve otherwise unattainable goals domestically, such as economic growth. In addition, EU institutions enhance national leaders' autonomy and initiative vis-à-vis special social groups (Moravcsik 1993: 507). The governments most motivated to reach an agreement will dedicate greater effort to negotiations and more likely make concessions. Large, wealthy member states tend to be most influential in negotiations over policies affecting public goods (Moravcsik 1993: 499-500). Therefore, representatives of France, Germany, Italy, Spain and the United Kingdom would be expected to work most intensively and provide the necessary concessions to achieve a final agreement. Reaching an agreement would further avoid the large reputational costs of the EU's failure to take a credible stance before Paris 2015 climate negotiations.

LI emphasizes that industries significantly affected by negotiated legislation in terms of per capita gains or losses also exert greater influence, particularly the "losers" (Moravcsik 1993: 483-488, 505). National energy industries, e.g. the utilities industry, the renewables industry, the petroleum industry and energy-intensive industries are all expected to impact the negotiating position of their respective countries. LI mainly expects that negotiation outcomes can be understood as a compromise wherein the largest member states hold the most weight. The most affected industries are also expected to heavily influence their government's negotiating position.

This article will not only inquire into the roles of specific key member states including France, Germany, Italy, Poland, Spain and the United Kingdom, but also discuss the positions of other member states in the 2013-2014 negotiations. These countries were chosen as they have the largest populations as well as the largest gross domestic products of the EU (Eurostat 2015a, 2015b). These parameters are part of the so-called aggregate structural power, considered essential in explaining power in the European Council (Tallberg 2008: 689). 
Poland has been included both for being the largest and wealthiest Eastern European member state (Eurostat 2015a, 2015b), and because of its leadership role among these countries, which have historically played the "veto card" in EU climate and energy negotiations resulting in concessions/side payments (Braun 2014: 450-451). Major industries in this context are the national utilities industry, the renewables industry, the petroleum industry and the energy intensive industries. These industries both affect and are influenced by the respective member states' energy systems, energy politics and energy policies (Ydersbond 2016). Thus, it is of great interest to examine the potential connections between the political positions of the member states in the 2030 negotiations, their domestic climate and energy policies, and the structure of their energy systems.

\section{The Advocacy Coalition Framework}

Advocacy coalitions are defined as persons or groups who 1) share policy core beliefs, and 2) have a non-trivial degree of coordination and cooperation over a long period of time. Policy core beliefs are what a coalition finds normatively important, addressing how the coalition believes challenges should be solved (Sabatier 1998: 103). In the present case, policy core beliefs include questions like whether implementation of EU sustainability policies will impede or enhance economic growth and competitiveness. Policy core policy preferences are exactly how a stakeholder wants a policy core belief to be translated into practice, i.e. their concrete suggestions for policy (Jenkins-Smith et al. 2014: 191). Advocacy coalitions regularly try to influence political decision-making within their policy subsystems, here the EU's climate and energy policy. These are, in turn, shaped by policy topic, geographic area and the stakeholders attempting to influence the given domain.

Additionally, the policy subsystem often has some formal authority. Usually advocacy coalitions consist of a variety of participants, including representatives of legislators at multiple government levels, agency officials, interest group representatives, researchers, politicians, journalists and others (JenkinsSmith et al. 2014: 189-190). The advocacy coalitions in this study include stakeholders seeking to influence the EU's 2030 Framework, such as interest groups, member states and companies. Coalition formation is clearly evident in the interest group community, which makes combining the ACF with interest group research approaches an interesting avenue of research (Rozbicka 2013: 846).

Four mechanisms explain policy change within the ACF. First, major external events like regime change and crises may not only place constraints on stakeholders' operating conditions, but also open up "windows of opportunities." These events can be understood as external shocks. Second, internal shocks, for example political fiascos or failures, may significantly impact and 
even lead to policy changes. Third, policy change may be a result of policy-oriented learning by coalition members. In such cases, policy change is likely to be incremental. Last, policy change may be a result of "a negotiated agreement between previously warring coalitions" (Jenkins-Smith et al. 2014: 201-203). It is reasonable to believe that no single advocacy coalition has the power to completely dominate such a weighty and diverse field as the EU's climate and energy policy. Thus, the policy change, herein the 2030 Framework, is likely a compromise between various advocacy coalitions. Research on EU climate and energy policy has documented advocacy coalitions in the utilities industry, in the renewables industry and environmental organizations and potential coalitions in the energy intensive industries during the 2020 Climate and Energy Package negotiations (Ydersbond 2012, 2014; Sattich 2013: 202-204). Since advocacy coalitions typically operate for at least a decade (Sabatier 1998), such coalitions would be expected also to influence the 2030 Framework.

The ACF's main expectations are that the 2030 Framework may be understood as a compromise amongst various advocacy coalitions. The following coalitions are likely active: a) a "green" coalition consisting of, for example, the renewables industry and environmental NGOS; b) the utilities industry; and c) the energy intensive industries.

In the 2030 negotiations, advocacy coalitions' potential policy core beliefs and policy preferences may include:1) whether they argue for zero targets, one main target or three overarching targets; 2) whether they propose binding targets for renewable energy, energy efficiency and reduction of greenhouse gas (GHG) emissions; 3) whether they prefer national-level or EU-level targets; and 4) their expressed levels of ambition, e.g. if they argue for a GHG emissions reduction of $35 \%$ or $40 \%$. "Non-trivial degree of coordination" will be assessed based on the groups' participation in joint meetings, their release of joint press statements, reports and letters, and organization of joint public events all over longer time spans, qualifying as strong forms of coordination in the ACF (Jenkins-Smith et al. 2014: 197).

\section{Historical Institutionalism}

Historical Institutionalism acknowledges that member states are key to understanding European integration, but also holds that EU institutions must be adequately considered in explaining decision-making processes over time (Pierson 1996). That present choices are affected, and often determined by, governmental systems' previous policy choices which become institutionalized practices, is called path dependency (Krasner 1984). When an institution is firmly established, its structure is difficult to alter, resulting in so-called institutional stickiness (Pierson 2000: 490-491). This is not least caused by public organizations' established routines, standard operating procedures (SOPs), and 
the sets of ideas upon which institutions are based. Positive feedback effects make system changes even more difficult. Transfer of legislative competence and expansion of EU-level legislation is related to: a) the autonomous action of EU-level institutions and their institutional self-interest, such as securing a negotiated agreement, achieving the EU's long-term targets and increasing the respective institutions' own autonomy; b) national decision makers limited in their capacity to have a complete overview of increasingly complex and comprehensive EU policies, thereby making legislation vulnerable to EU-level institutions manipulating them for purposes not originally part of discourse; c) national decision makers constrained by the logic of re-election, while EU decision makers can choose longer time horizons; and d) shifting member state preferences, for example when there is change of government (Pierson 1996:131-148). Occasionally, in relatively short periods of time, decision makers may have exceptional leeway to implement major legislative changes at critical junctures, such as when there has been an external shock like a war, a large economic crisis or a geopolitical crisis (Capoccia \& Kelemen 2007: 348-350).

Herein, the most interesting institutions are the Commission, the European Parliament (hereafter, Parliament) and the European Council. In addition, it is relevant to assess how the 2030 Framework relates to its predecessor, the 2020 Climate and Energy Package. The Commission has long sought to position the EU as a global environmental leader, improve energy security, and create an internal energy market for gas and electricity. To this end, the Commission may be expected to deploy its agenda-setting power, negotiating skills and oversight in negotiation processes, strengthening the EU's institutional capacities and maintaining a high level of ambition in its climate and energy policy. The Parliament is expected to work for an ambitious framework, since it has traditionally been the "greenest" of EU institutions (Burns et al. 2013).

The main expectation of HI is that the 2030 Framework may be understood as a path-dependent outcome of existing rules, norms, values and ideas. Furthermore, the Commission and the Parliament exercise agenda-setting power.

To what extent can the new 2030 Framework be described as a path-dependent outcome of rules, norms, values and ideas of the previous EU climate and energy frameworks, particularly the 2020 targets? Path dependency may be seen in the connections between overarching frameworks, directives, roadmaps and targets historically decided upon at the EU level. The Commission and Parliament are considered because they are arguably the most supranational of the EU's bodies. In contrast, the Court of Justice of the European Union (CJEU) was not involved in issues directly related to negotiations, while the European Council is best considered an intergovernmental body 
(Egeberg 2012: 946-947). The Commission and Parliament's powers will be conceptualized through an assessment of influence.

\section{Methodology}

Case studies enable process tracing of causal mechanisms posited by various theories. Here, testing hypotheses derived from LI, ACF and HI may clarify the conditions under which these hypotheses are generalizable (Bennett \& Checkel 2015: 13). The "most-likely" case design implies that if the hypotheses are not supported, the theories from which they are derived will have significantly lower explanatory value on similar cases (Eckstein 1975). This study's results may thus provide material for analytical generalizations, generalizations to potential populations of cases with similar features (Yin 2009), including other negotiations on controversial issues in EU climate and energy policy at the highest political level. Complementary theory testing is conducted in this study, akin to the domain of application approach by Jupille et al. (2003: 21-22, 29).

$\mathrm{HI}$ and the ACF are relevant for the study of policy processes which unfold over several years. Thus, this article follows political processes from 2007 onward. The first Climate and Energy Package represented a critical juncture in EU climate and energy policy making, providing a relevant starting point for process tracing. However, this article's main focus is the processes starting from 2012 onward when discussions about the 2030 Framework gained prominence in EU political debate.

Data for mapping and understanding the political processes were gathered from a wide range of sources. Altogether, 37 semi-structured research interviews are used, based on three rounds of interviewing during negotiations in 2014, autumn/winter 2014, and autumn 2015 . $^{3}$ The objectives were to record specific insights and reflections of key stakeholders on the political processes, better understand the political positions of their respective groups, scrutinize their rhetoric and, whenever possible, collect first-hand information on politically sensitive issues such as lobbying strategies and coalition making. Interviewees were selected based on their organizational affiliation and proximity to the political process, and may be considered key/elite informants. Other sources include Communications, White and Green papers from the Commission, minutes of meetings in the European Parliament, responses to public hearings arranged by the Commission on the 2030 Framework and

3 See Appendixes 2 and 3 in the supplementary material, online at 10.6084/mg.figshare.6825899, for further details about these interviews. 
energy efficiency, and various Council documents. EU media channels were additionally monitored.

Primary indicators of stakeholders' political positions are the targets set for renewable energy, energy efficiency and GHG emissions reduction, as formulated in the 2030 Climate and Energy Policy Framework and agreed upon in the Council meeting October 23-24, 2014. Specific indicators include: domestically reducing GHG emissions at least 40\% compared to 1990 levels; an EU-level target that at least $27 \%$ of energy consumed comes from renewable energy sources; and an indicative target that energy efficiency improves at least $27 \%$ relative to projections (Council 2014d). Other parts of the 2030 Framework will be discussed further on in the analysis.

Power in this context is measured through a three-fold operationalization of influence. First, influence can be measured as the proximity between the negotiating positions of various stakeholders and the final formulations of the 2030 Framework, called attained influence. Second, influence can be mapped by conducting process tracing to analyze the political processes as closely as possible. Third, a less direct measurement of influence is obtained in data on who participants considered to be powerful, as stated in interviews, public debates, press releases, and newspaper interviews. This is called attributed influence (Dür 2008: 562-569). For a stakeholder or stakeholder group to qualify as influential in the final analysis, it needs to have high attained influence (i.e. little/no distance between political position and outcome) and attributed influence on the 2030 Framework (in the stakeholder interviews or the press). ${ }^{4}$

\section{The 2030 Negotiations}

The first Climate and Energy Package, upon which the 2030 Climate and Energy Policy Framework builds, stipulated that by the year 2020: the EU was to reduce GHG emissions by $20 \%$ from 1990 levels; member states were to have binding national renewable energy targets, leading the EU to consume $20 \%$ of its energy from renewable energy; and that energy efficiency (indicative target) should be improved by $20 \%$ compared to projected levels. These provisions were termed the "20-20-20" targets (Council 2007). However, after agreeing to the overarching targets for 2020, Europe was struck by economic crisis, which engendered a public discourse more concerned with losing economic competitiveness than with sustainability. The EU's public agenda has

4 Further methodological considerations are presented in Appendix 3, online at 10.6084/ mg.figshare.6825899. 
furthermore been affected by geopolitical crises. The Russian gas delivery boycotts of 2006/2007 and 2009 pushed energy security to the top of the agenda for both member states and EU leaders.

Political negotiations leading to the 2020-2030 EU climate and energy legislation unfolded over several years. From 2012 onwards, stakeholders discussed the ambition level for the GHG emissions reduction target, such as reductions of $35 \%, 40 \%$ or $45 \%$ (Interview, Union of the Electricity Industry [Eurelectric] 2014b). The formal legislative process was initiated by the Commission in spring 2013 when it issued a Green Paper on the new framework (Commission 2013a). In the summer of 2013, the Commission arranged a hearing/consultation where it received a total of 557 responses (Commission 2013b). The issues raised proved controversial, with the stakeholders in the Commission, Parliament, member states, interest group communities and others disagreeing severely on all aspects.

In the autumn of 2013, a total of 13 environment and energy ministers, including the United Kingdom Secretary of State for Energy and Climate Edward Davey, met to create momentum for a more environmentally oriented negotiation outcome. They introduced themselves as the Green Growth Group (GGG) (Davey 2013; G G G 2013). Spring 2014, the G G G asked for a binding domestic G HG emissions reduction target of at least $40 \%$, an EU-wide renewable energy target of at least $27 \%$ and for the 2030 Framework to include an energy efficiency target (GGG 2014). Several of the ministers in the GGG also represented countries which worked together informally for binding and comparatively ambitious targets (herein: the Ambitious Group of Member States), consisting of Austria, Belgium, Denmark, Germany, Ireland, Luxembourg, Portugal and Sweden (joined in the end) (Council 2014a; Flynn 2014; Greenpeace 2014: 4; Interviews Bundesverband Erneuerbare Energie [BEE] 2014a, European Renewable Energy Federation [EREF] 2014a, European Wind Energy Association [EWEA] 2014, EWEA 2015 and Friends of the Earth Europe [FoE] 2014; Lidegaard 2013; Mitterlehner et al. 2013; Romson 2014).

Pitted against this group of "green" member states stood the Visegrad+ Group, led by Poland. It consisted of the original Visegrad countries - the Czech Republic, Hungary, Poland and Slovakia - subsequently joined by Croatia, Bulgaria and Romania. Croatia later left the group (Visegrad Group 2014a, 2014b, 2014c). In the summer of 2013, the Czech Republic and Romania maintained that targets should be set only in the case of a global agreement at the December 2015 Paris Protocol meeting. Poland contended that the 2030 Framework should not be agreed upon until 2015 at the earliest (Commission 2013b). The Visegrad+ Group argued that, given their economic situation and capacity for implementing what they perceived as costly and burdensome 
measures, which could potentially lead to so-called "carbon leakage," there should only be one EU target for reducing GHG emissions. ${ }^{5}$ Throughout the negotiations and until the final Council summit in October 2014, the Visegrad+ Group threatened to veto the 2030 Framework (e.g. Visegrad Group 2014b, 2014c). Several interviewees had the impression that the Visegrad+Group ultimately fell apart (e.g. Interview Third Generation Environmentalism [ $\left.\mathrm{E}_{3} \mathrm{G}\right]$ 2014). Despite such public positioning, assessing individual member states' political positions was far from straightforward; several did not disclose them publicly, some changed positions, and some took positions late. Their declared or estimated positions prior to the final negotiations were as outlined below in Table 1.

In January 2014, the Commission issued a communication proposing the headline targets to guide EU's climate and energy policies from 2020 to 2030. They were: a reduction of GHG emissions by at least $40 \%$, an EU-wide binding target for renewable energy of at least a $27 \%$ share of total EU energy consumption, and "higher ambitions" than in EU's energy efficiency policies. The actual target for energy efficiency was left open until summer 2014 (Commission 2014c). The Parliament aspired to steer the EU toward a "greener" direction, and in January 2014 launched an initiative report (Interview European People's Party group [EPP] 2014; Parliament 2014a). February 2014 in plenary, the Parliament voted in favor of a GHG emissions reduction target of at least $40 \%$, a nationally binding renewables target of at least $30 \%$, and a binding energy efficiency target of $40 \%$. The final political positions of the Commission and the Parliament on the targets are presented below in Table 2.

Russia invaded the Crimean Peninsula in February 2014, contributed to the outbreak of civil war in Southern and Eastern Ukraine and cancelled gas-purchasing contracts to Ukraine. Several Southern and Eastern European countries were heavily dependent upon imports of Russian gas, and many of their gas pipelines passed through Ukraine. Therefore, this Russia-Ukraine crisis also pushed European energy supply security to the top of the EU and member state leaders' agendas (e.g. Commission 2014c). And the public eye again shifted from economic competitiveness to energy supply security (Interviews, Alliance of Liberals and Democrats for Europe group [ALDE] 2014; Climate Action Network [CAN] 2014; Coalition for Energy Savings [CoE] 2014; Directorate-General [DG] Energy 2014a; European Climate Foundation [ECF] 2014; Eurelectric 2014a; The European Union of

5 Carbon leakage means that industries relocate to other countries because environmental regulations there are less strict, which may lead to increased total emissions of greenhouse gasses from these industries. 


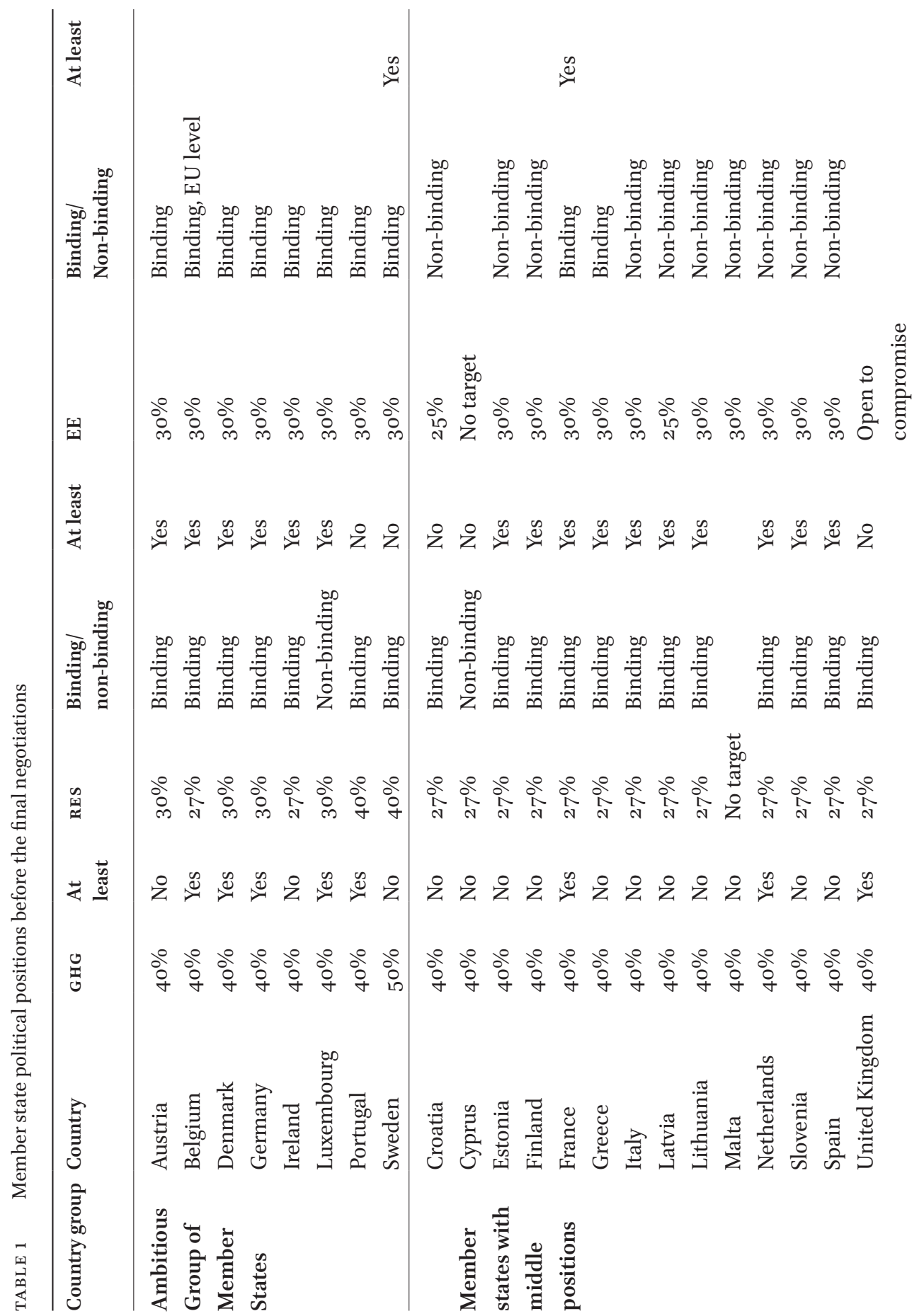




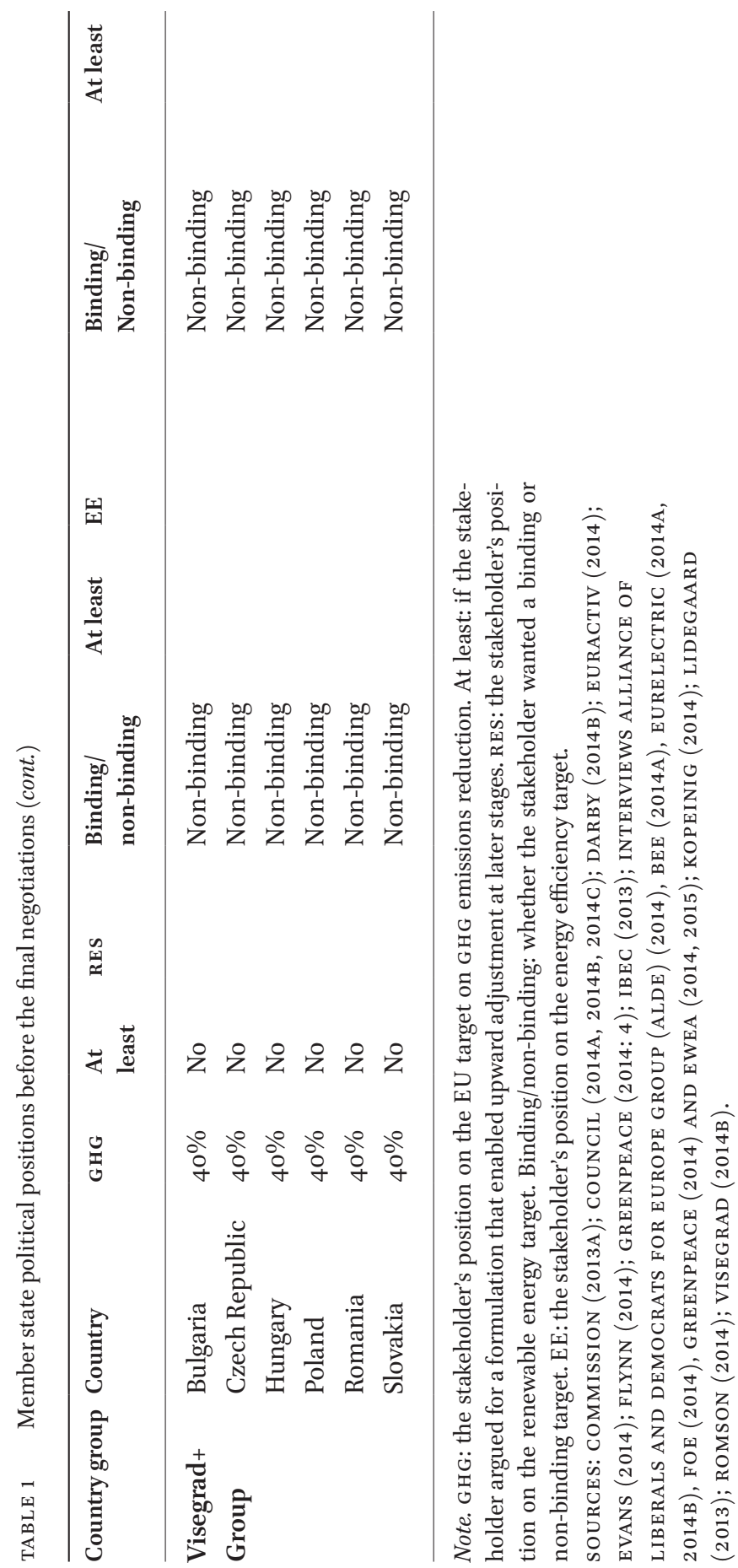


TABLE 2 Political positions of the EU's supranational institutions

\begin{tabular}{|c|c|c|c|c|c|c|c|c|}
\hline Name & GHG & $\begin{array}{l}\text { At } \\
\text { least }\end{array}$ & RES & $\begin{array}{l}\text { Binding/ } \\
\text { non-binding }\end{array}$ & $\begin{array}{l}\text { At } \\
\text { least }\end{array}$ & $\mathrm{EE}$ & $\begin{array}{l}\text { Binding/ } \\
\text { non-binding }\end{array}$ & $\begin{array}{l}\text { At } \\
\text { least }\end{array}$ \\
\hline Commission & $40 \%$ & No & $27 \%$ & $\begin{array}{l}\text { Binding, } \\
\text { EU level }\end{array}$ & Yes & $30 \%$ & Non-binding & No \\
\hline $\begin{array}{l}\text { European } \\
\text { Parliament }\end{array}$ & $40 \%$ & Yes & $30 \%$ & $\begin{array}{l}\text { Binding, } \\
\text { MS level }\end{array}$ & Yes & $40 \%$ & Binding & No \\
\hline
\end{tabular}

SOURCES: COMMISSION (2014A: 15, 2014B: 17); AND PARLIAMENT (2014B: 470-471).

the Natural Gas Industry [Eurogas] 2014; FuelsEurope 2014 and Greenpeace 2014). Originally, the 2030 Framework was to be agreed upon at the March 2014 Summit. The decision was postponed for half a year due to severe disagreements and the Russia-Ukraine crisis. Interest groups seized this window of opportunity to lobby massively for various solutions. Energy security concerns made members of the European Parliament (MEPs) and the Commission more supportive of an ambitious energy efficiency target (Interview ALDE 2014). The Commission scaled up the summer 2014 energy efficiency target proposal to $30 \%$ rather than the $25 \%$ that would have arisen from implementing the $40 \%$ GHG emissions target (Commission 2014b: 17).

Three advocacy coalitions in the interest group community can be identified from the collected data: 1) the utilities industry with the umbrella organization Eurelectric, member organizations, several of their member companies, the trade union IndustriAll Europe and the European Public Service Union (EPSU) (Eurelectric, IndustriAll \& EPSU 2014; Interview Eurelectric 2014b); 2) a large group of actors collectively labelled the "Broad Green Community," containing European environmental organizations, the European renewable energy industry, European groups working for improved energy efficiency, these respective groups' national members, and other affiliates such as the ECF and the MEP group "the European Forum for Renewable Energy Sources (Eufores) (Interviews CAN 2014; EREF 2014a; 2014b; Greenpeace 2014; and ECF 2014; EUFORES 2013); and 3) the energy-intensive industries under the umbrella Alliance of the Energy Intensive Industries (AEII) and their national members (interview FuelsEurope (previously called Europia) 2014).

The first coalition worked for an overarching GH G emissions reduction target of at least $40 \%$, and aligning targets for renewable energy and energy efficiency. The GHG target should be achieved via the EU emissions trading system (EU ETS) (Eurelectric 2013, 2014). Members of the Broad Green Community called for a reduction of GHG emissions by at least $55 \%$, a nationally binding 
renewables target of $45 \%$ and an energy efficiency target of $40 \%$ (CAN 2015; $\mathrm{CoE}$ et al. 2013a, 2013b and 2013c). The AEII coalition argued for a single GHG emissions target, to be implemented only in the case of a global climate agreement. They were also against EU ETS reform to prevent "carbon leakage" and loss of competitiveness. AEII held that higher ETS prices would induce industries to relocate to elsewhere in the world (AEII 2013a; 2013b; 2014).

These three advocacy coalitions expended multiple channels to influence political negotiations, including holding meetings with relevant politicians and officials at various political levels, organizing events, publishing press releases and reports, briefing journalists and participating in public hearings. Other advocacy coalitions might also have lobbied to influence the 2030 Framework, e.g. the petroleum industry (Neslen 2015). The petroleum refining industry interest group FuelsEurope is a member of AEII. Moreover, the petroleum producer industry umbrella organization International Organization for Oil and Gas Producers (IOGP) ${ }^{6}$ shared AEIIs views. The political positions of the selected non-governmental stakeholders are summarized below in Table $3 .{ }^{7}$

The Visegrad+ Group was not alone in playing the veto card. Spain and Portugal had long struggled with poor electricity grid interconnection with mainland Europe, aggravated by their investments in large-scale expansion of wind and solar power. The Iberian countries therefore threatened to veto the final agreement if the summit did not include enhanced interconnectivity ambitions (Crisp 2014; Darby 2014a, 2014b; Interview Union Française de l'Électricité [UFE] 2015; Neslen 2014). These countries and their cause were supported by the Baltic States, which also had low electricity grid interconnection and depended on imports of Russian power (Fischer 2014).

There was great uncertainty regarding whether member state leaders would agree on a 2030 Framework at the Council summit in October 2014 (Keating 2014). Yet, they were able to forge an agreement following lengthy negotiations that extended into the summit with Poland (Traynor \& Neslen 2014). Several changes to the Framework were made at the Summit (see Council 2014d, 2014e). Chancellor Merkel and President Hollande worked until the very end of the Council summit to secure an agreement (Süddeutsche Zeitung 2014). The resulting 2030 climate and energy targets were as follows: a binding target of at least $40 \%$ domestic reduction in G HG emissions compared to 1990 levels; an EU-wide binding target of at least $27 \%$ renewable energy consumption; an indicative target of at least $27 \%$ increased energy efficiency; and a minimum $10 \%$ grid interconnection by 2020 , with the Commission working to achieve $15 \%$

6 Previously, IOGP was abbreviated as OGP.

7 These advocacy coalitions' policy core beliefs are described in detail in Appendix 4, online at 10.6084/mg.figshare.6825899. 


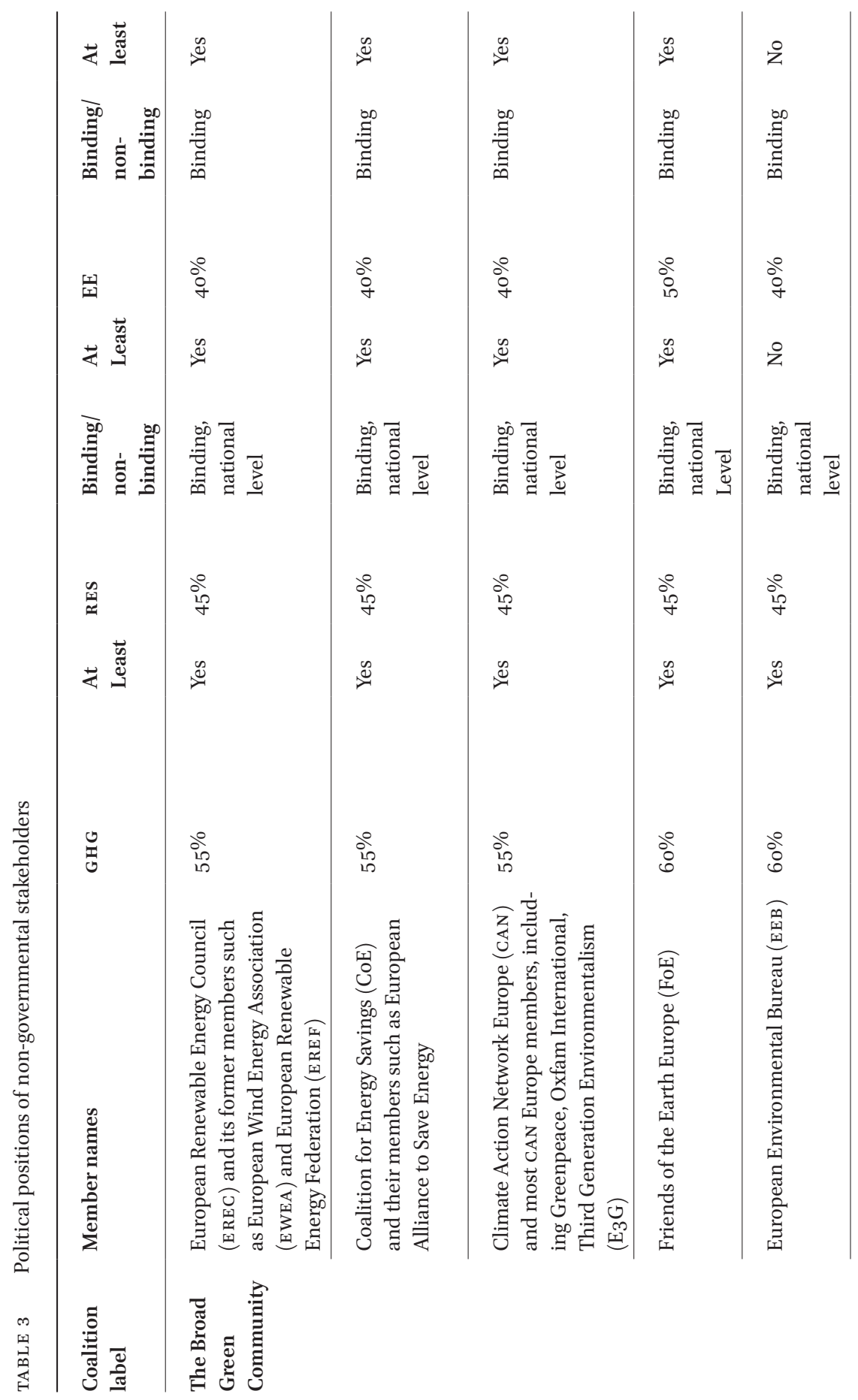




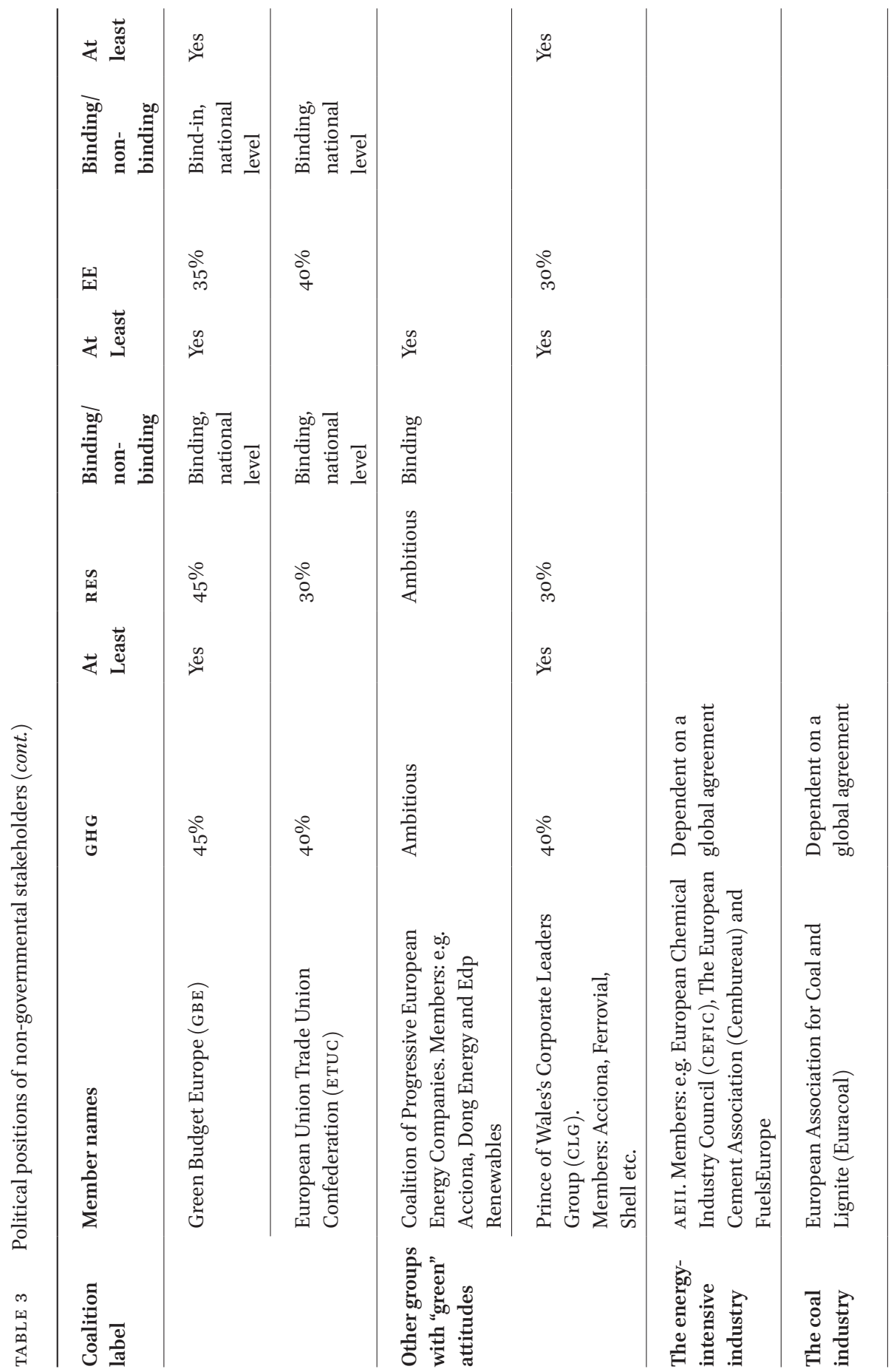




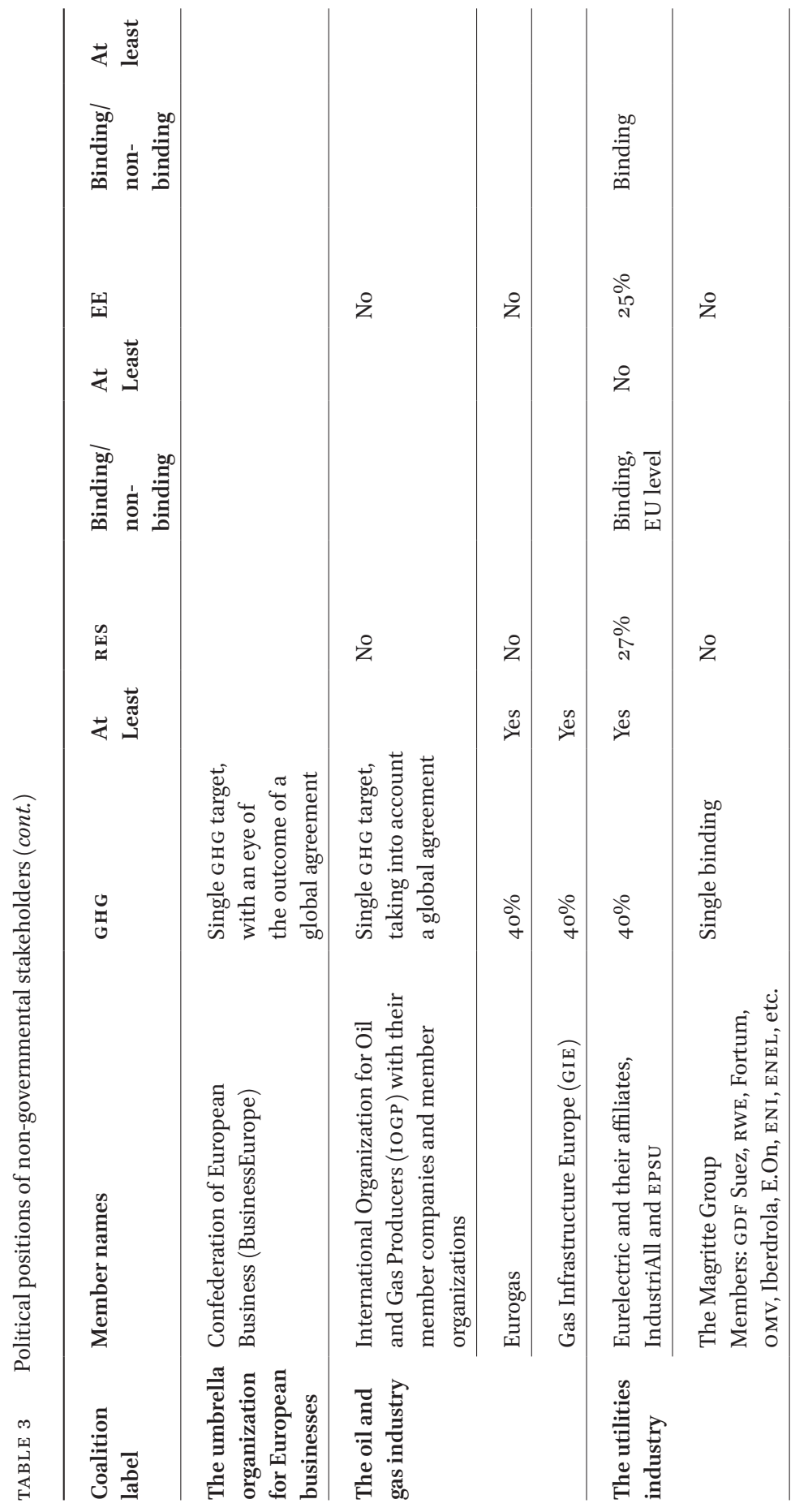




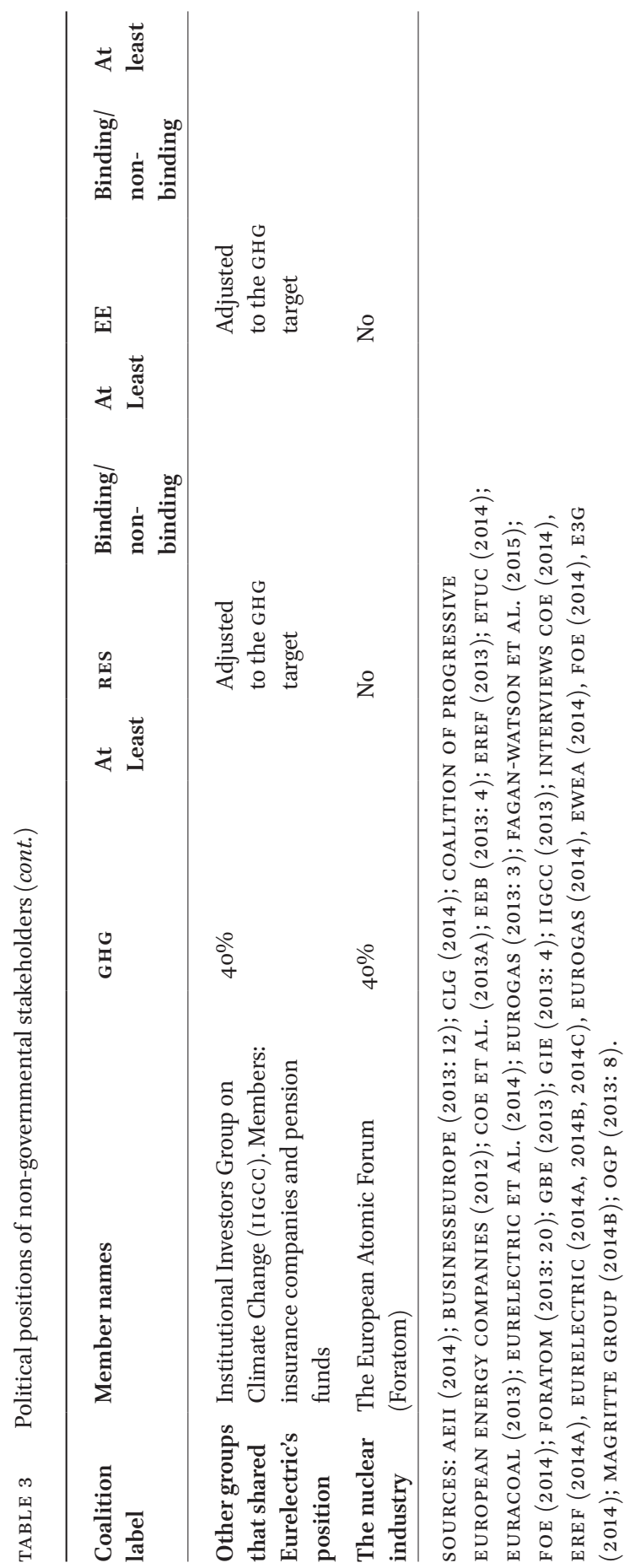


interconnection by 2030. The energy efficiency target will be reviewed in 2020, with a view to increasing it to $30 \%$. In addition, several other important points were included, among them the reform of the EU ETS. To get the Visegrad+ Group "on board," they were given incentives including free emission allowances in the EU ETS, making it considerably cheaper for them to implement policies to reduce GHG emissions, increase renewable energy production and improve energy efficiency (Council 2014d). With these incentives, the Polish Prime Minister declared that Poland had "won" the negotiations (Gotev 2014).

\section{Who Got What in the End?}

\section{Liberal Intergovernmentalism's Explanatory Power}

Several features of this analysis support the explanatory value of hypotheses derived from LI. Interview data, secondary literature and the overlap between political positions, strategies and outcomes indicate that the largest member states exercised the greatest leverage. Germany invested substantial political effort into securing an agreement. France, as the host of the upcoming global climate negotiations in Paris, and Italy with the Council presidency, were also eager to achieve a final agreed framework which would give the EU a credible and ambitious position before the upcoming global climate negotiations. The United Kingdom pressed for an overarching G HG emissions target and was also strongly critical to a binding national renewables target (Interview EWEA 2014; Neslen 2015). Poland threatened to veto until the final negotiating hours in order to achieve "concessions." All these strategies were ultimately reflected in the 2030 Framework. The largest member states therefore seemed to have largely succeeded in pushing their agendas.

While assessing member state influence, it must be noted that groups of member states - the Visegrad+ Group, the Iberian countries and the Ambitious Group of Member States - were influential and crucial. The data and final 2030 Framework indicate that the Poland-led Visegrad+ Group and the Iberian countries' veto strategies also proved decisive to the outcome, demonstrated by: a) the "concessions" given to the Visegrad+ Group, and b) electricity grid interconnection being deemed an EU priority and included for the first time in the EU's overarching climate and energy policy. The 2030 Framework's level of ambition was influenced by the Ambitious Group of Member States: there were three final overarching targets, two of which could be adjusted upward later.

There is also some data to support the second part of LI's expectation: the most severely affected national industries in the largest member states 
influenced their respective governments' positions. The proximity between the political positions of the United Kingdom's government and its major business associations (Confederation of British Industry [CBI], Energy UK [CBI 2013; Energy UK 2013] and the United Kingdom's petroleum industry [BP 2013]), and the Polish government and its energy industry and business associations (Mouvement des Enterprises de France [MEdef] et al. 2014; Polski Komitet Energii Electrycznej [P KEE] 2014) is likely no coincidence. The comparatively ambitious stance of the German government was also likely influenced by a population very supportive of renewable energy and energy efficiency, a sizable renewables industry, a large environmental movement and a large utilities industry (e.g. BEE 2014). However, the stances of French, Spanish and Italian governments seemed to hedge the positions of their relevant industries, indicating that diverging industrial positions can also influence governments to take midline positions.

In terms of attained influence, the $40 \%$ GHG emissions reduction target meant that most member states achieved their final preferences. Although this outcome diverged radically from half of its members' initial positions, the Visegrad+Group also attained their preferences to some extent through the "concessions" obtained from their veto card. Most of the member states with middle positions, plus Belgium and Ireland, achieved their position in the $27 \%$ renewable energy target. Since the target was binding only at the EU level, and subsequent decisions regarding its implementation were under veto power, this result may still be regarded as a partial preference fulfilment for the Visegrad+ Group. In contrast, the inclusion of the wording "at least" and "binding" reflects some degree of achievement for the Ambitious Group of Member States, as these formulations allow for future upward adjustment of targets and commits the EU to work for renewable energy growth. The Ambitious Group of Member States also attained its preferences in that the 2030 Framework ultimately had three headline targets. No member state attained their preference in relation to the energy efficiency target. The "at least" formulation, which enabled upward adjustment at later stages, may be viewed as a partial preference fulfilment for the Ambitious Group of Member States. However, the energy efficiency target's non-binding nature was in line with preferences of the least ambitious member states, i.e. the Visegrad+ Group and member states arguing against an energy efficiency target, such as the United Kingdom.

For attributed influence, France, Germany, Italy, Poland and the United Kingdom were seen as influential by interviewees and the press: France and Germany for securing an agreement, Poland and the United Kingdom for vetoing stronger targets for renewable energy and energy efficiency, and the United Kingdom and France for awarding high status to the GHG emissions reduction 
target (Casinge 2014; Die Zeit 2014; Der Spiegel 2014; Fischer 2014; Interviews EREF 2014b, BEE 2015 and independent consultant 2014; Uken 2014). Italy, which held the presidency during negotiations, viewed itself as the "godparent" of the interconnector target (Interview Statnett 2015). The Ambitious Group of Member States were seen as instrumental to the inclusion of renewable energy's binding target, the "at least" formulations for renewable energy and energy efficiency, and that the 2030 Framework ultimately had three targets (Interviews BEE 2014 and FoE 2014). Portugal and Spain were attributed responsibility for the inclusion of a binding interconnection target of $10 \%$ by 2020 and the "arriving at $15 \%$ interconnection by 2030 " formulation in the final 2030 Framework (Interviews E3G 2014, EWEA 2015 and UFE 2015). The analysis shows that there was fairly large overlap between the attained and attributed influence of member states. The most and least ambitious member states did not achieve their preferences regarding renewable energy and energy efficiency targets, which demonstrates that the final 2030 Framework was a genuine compromise where all member states had to "give and take."

Furthermore, there were systematic patterns of connection between the political positions of member states and their domestic energy policies and energy systems. This is documented in Table 1 and in Appendix $5 .{ }^{8}$ The size and power of the member states' industries are related to their energy systems' physical structures, overarching political decisions and the energy policies implemented by their governments in recent decades. Most members of the Ambitious Group of Member States - such as Denmark, Germany, Ireland, Portugal and Sweden - that pushed for the three binding and ambitious targets, had already implemented relatively ambitious renewables, energy efficiency and GHG mitigation domestic policies. Several of these states also intended to further these policies, setting ambitious domestic long-term targets for mitigating GHG emissions, increasing renewable energy and improving energy efficiency. Most of them already have a high share of their electricity generated from renewable sources. None except Germany produce coal domestically. Furthermore, these countries (except Denmark, which will likely have little petroleum left for extraction in the next decades) have few or no indigenous petroleum resources, leading to a substantial petroleum import dependency. Generally, they have either phased out nuclear power entirely (Germany), have banned nuclear electricity generation (Austria, Denmark, Ireland, Luxembourg and Portugal), or have implemented stricter regulation enabling gradual phasing-out of nuclear power (Belgium and Sweden). Governmental policies in the Ambitious Group of Member States tend to reflect skepticism to carbon capture and

8 Appendix 5 canbefoundinthesupplementarymaterial,onlineat10.6084/mg.figshare.6825899. 
storage (CCS). Last, several of these member states have previously taken "green" positions in EU negotiations related to climate and energy.

In contrast, the governments of member states with large domestic petroleum production, specifically the Netherlands and the United Kingdom, argued for only one target for $\mathrm{G} \mathrm{H} \mathrm{G}$ emissions reduction, which should be reached via the EU ETS. They also actively promoted cCs. Member states opting for a single or overarching target were also the states that had planned expansion of their nuclear energy production, such as the Visegrad+ Group members, Finland, the United Kingdom, and member states prolonging the lifetime of existing nuclear facilities, i.e. France and Slovenia. Member states holding the least ambitious political positions, i.e. the Visegrad+ countries, have high shares of coal, substantial shares of nuclear power and low shares of renewable energy in their energy mixes. ${ }^{9}$ Domestic coal production is also considerable, and most rely heavily on imported oil and gas. Half of the governments appear positive to domestic shale gas extraction. Visegrad+ members' energy policies seem to be strongly influenced by de facto locked-in coal production and consumption. They have not set specific, binding, long-term, domestic targets for renewable energy and energy efficiency. In the short and medium term, heavy investments in non-renewable infrastructure and lobbying from the energy industry impede the remodeling of the Visegrad+ countries' energy systems. Last, these states' defensive political positions were also likely linked to their experiences in implementing the 2009 climate and energy package (Skjærseth et al.: Ch. 10).

\section{The Advocacy Coalition Framework's Explanatory Power}

The data provides mixed support for the ACF expectations. The anticipated long-term advocacy coalitions in the utilities industry, between environmental groups and the renewables industry, and within the energy intensive industries were identified. The environmental groups and the renewables industry were joined by other groups committed to energy efficiency, thereby forming a "green" community larger than ever seen at the EU level: the Broad Green Community. However, from analysis and process tracing, it seems highly unlikely that the three advocacy coalitions identified in the interest group community were decisive in the outcome. That would imply that the national governments and the Commission had no influence. Thus, only if the advocacy coalitions are broadened to include stakeholders with comparatively similar positions can the 2030 Framework be conceptualized as a compromise

9 The energy mix of a country is the specific combination of different energy sources it uses to meet its energy consumption needs (tutor2u 2017, at: https://www.tutor2u.net/geography/ reference/energy-mix). 
between the different identified advocacy coalitions. These "new" advocacy coalitions may have had tentative coordination, e.g. accommodating their political strategies to achieve a shared target and/or shared information (Zafonte \& Sabatier 1998: 480). There is, in fact, some data indicating that such coordination existed (Interviews FoE 2014 and FuelsEurope 2014). Such potential grand overarching coalitions based on similar political positions are presented in Appendix 6. ${ }^{10}$

In terms of attained influence on the $40 \%$ GHG emissions reduction target, the utilities industry's advocacy coalition with Eurelectric and their partners, the European nuclear industry, the European gas industry and the Prince of Wales's Corporate Leaders Group (CLG) all attained their position. In contrast, only the advocacy coalition of Eurelectric and its partners attained their preference regarding the $27 \%$ renewable energy target. That the target was only binding at the EU level, and thus potentially difficult to implement, was in line with the preferences of stakeholders that opted for weak renewable energy policies: the advocacy coalition AEII and the groups BusinessEurope, Euracoal, Eurogas, Foratom, GIE, IOGP and the Magritte Group. The Broad Green Community saw their preference met to some extent in the "at least" formulation, although they regarded the final renewables target as extremely weak. The indicative energy efficiency target of at least $27 \%$ was not in line with any advocacy coalition's or group's position, though closest to the position of Eurelectric and its allies. Nevertheless, the fact that this target is only indicative meant it was de facto relatively in line with the preferences of AEII, BusinessEurope, Euracoal, Eurogas, Foratom, GIE, IOGP and the Magritte Group. In contrast, the opportunity for subsequent upward adjustment was viewed positively by the Broad Green Community. AEII did not achieve its target preferences, but their concerns were significantly met de jure by the in the 2030 Framework provision of free allocation of EU ETS quotas after 2020 to prevent so-called "carbon leakage."

In terms of attributed influence, opinions were mixed as to who in the interest group community was the most influential. Several interviewees thought the energy-intensive industries (e.g. AEII) and BusinessEurope were influential (Interviews CoE 2014; ECF 2014; Greenpeace 2014; FuelsEurope 2014; and Statnett 2014c), while others highlighted Eurelectric and their partners (Interviews Eurelectric 2014a; and Greenpeace 2014). Two mentioned the Broad Green Community (Interviews Brusselkontoret 2014; and FuelsEurope 2014). Green MEPs attributed influence to the fossil fuel industry for watering down the energy efficiency target (Casinge 2014b). Here, we see that the industries seem to attribute their main "ideological adversaries" more power 
than an analysis of attained influence can support. A reason for this may be that interest groups in highly conflictual situations view their opponents as more influential and "evil" than is the case, described as "the devil shift" in ACF literature (Sabatier et al. 1987). Still, some interviewees saw the targets as a compromise between the various industries (Interviews Eurogas 2014 and FuelsEurope 2014). Such a perception indicates that some interest group community stakeholders perceive their own influence as larger than the objectively attained influence, in line with recent research (Newmark \& Nownes 2017). Moreover, three interviewees highlighted that influence was probably shared among several stakeholders: the member states, the EU's supranational institutions and the interest group community (Interviews Brusselkontoret 2014; Eurelectric 2014b; and FuelsEurope 2014). Such a fine-grained understanding may be attributed to how closely lobbyists follow political processes, therefore abstaining from simple generalizations as they understand how many stakeholders are involved in the decision-making.

\section{Historical Institutionalism's Explanatory Power}

Hypotheses based on HI also receive mixed support in the data. The Commission has used its right of initiative and the competence it has been assigned from the 1986 Single European Act, the 1992 Maastricht Treaty and the 2009 Lisbon Treaty over issues related to the creation of the internal energy market, to European climate policy and to external energy affairs. In so doing, it gradually expands its legislative competence, bureaucratic capacity and the scope and extent of EU legislation in the field of climate and energy to previously unforeseen levels (e.g. Boasson \& Wettestad 2013; Tosun et al. 2015; Wettestad et al. 2012). This is akin to what Pierson (1996) described as autonomous action and institutional self-interest from EU-level institutions which gradually lead to a transfer of legislative competence. Parallel to this development, pre-existing EU legislation, norms and practices seem to have conditioned subsequent paths regarding both the kind of overarching targets being set and the measures to attain them, i.e. there was path dependency. Since the implementation of the EU's climate and energy policy, there has been a focus on reducing G HG emissions, expanding renewable energy production and improving of energy efficiency. New EU directives, regulations, decisions, communications and roadmaps are normally built upon existing ones. Moreover, the legislation to attain overarching targets has tended to become increasingly comprehensive (e.g. Benson \& Russel 2015). This development is documented in Appendix $7 .{ }^{11}$ One notable feature breaks with the trend of increasing ambi-

11 See Appendix 7, online at 10.6084/mg.figshare.6825899. 
tion: although the $27 \%$ renewables target for 2030 is higher than the $20 \%$ target for 2020, it is still legally weaker since it is binding only at the EU and not the national level.

Looking at both attained and attributed influence, the data supports the agenda-setting power of the Commission, but not of the Parliament. The Commission achieved significant preference attainment, specifically regarding the $40 \%$ GHG emissions reduction target and the $27 \%$ renewable energy target. It was also viewed as a key actor through its agenda-setting power, indicating substantial attributed influence (Interviews Brusselkontoret 2014; Eurelectric 2014b; and FoE 2014). Contrarily, the Parliament did not attain its positions on the renewable energy and energy efficiency targets, and was attributed significant influence by only one interviewee (Interview Brusselkontoret 2014). Therefore, attained and attributed influence overlapped almost entirely for both institutions. Of course, the Commission's high preference attainment may have been caused by factors other than its agenda-setting power, such as insight into the preferences of all other stakeholders, for example, by "the rule of anticipated reactions" (Friedrich 1941: 589). Extensive consultation practices and massive lobbying by stakeholders gave the Commission a good grasp of stakeholder positions. This understanding enabled the Commission to propose policies with a high chance of member state acceptance, which was likely viewed as essential. A third potential factor may have been the strong disagreement between the leading Commission DGs, DG Climate and DG Energy (Bürgin 2014; Ydersbond 2016), contributing to a Commission policy framework proposal seen as a compromise.

The lack of Parliamentary influence appears to be counter recent research underscoring the Parliament's larger role in the EU at large (e.g. Hix \& Høyland 2013), but aligns with research arguing that the Commission is loath to change path despite the Parliament's best efforts to make legislation "greener" (Burns et al. 2013). As long as the Parliament consistently tries to pull EU policies decided in the European Council in a "greener" direction, it will also consistently fail in achieving high attained influence. Still, the Parliament is well positioned to exert greater influence at later process stages when the 2030 Framework's implementation legislation will be adopted in ordinary legislative procedure.

Other key concepts in $\mathrm{HI}$ and the ACF, such as the role of external shocks in explaining major policy change, seem relevant. The 2008 economic crisis and the Russia-Ukraine crises of 2006/2007, 2009 and 2014 may have been external shocks which substantially influenced EU climate and energy policies. The latter geopolitical event(s) made the Parliament more receptive to energy efficiency and the Commission more ambitious in its energy efficiency proposal of summer 2014. 


\section{Conclusion}

The 2030 Framework provided the EU with a credible and comparatively progressive mandate leading into the Paris 2015 international climate negotiations. All stakeholders - EU member state governments, key EU supranational institutions, advocacy coalitions - emerged with their preferences fulfilled to some extent, either de jure or de facto. The 2030 Framework seems to have genuinely compromised between stakeholder preferences.

Theory testing using case studies may illuminate the scope conditions of hypotheses. Expectations based on the three theoretical perspectives have received varied support from the data. Regarding LI expectations, the 2030 Framework can indeed be understood as a compromise where the largest member states held the weightiest influence. However, the 2030 Framework was also a result of coordinated action by groups of member state governments. Investigating such coordinated action and the exact basis for groups' common interest should be an avenue for future research on European Council climate and energy negotiations. Political positions of member states were aligned with key features in domestic energy policies, including: a) overarching strategic long-term climate and energy targets; b) structural traits of the respective states' energy systems and energy policies, such as whether they have opted for expansion or phase-out of nuclear energy production; and c) previous positions in EU climate and energy negotiations. These features should be considered in future applications of the LI perspective on EU negotiations in the field of climate and energy. For negotiators opting for sustainable solutions, analyzing member states' energy systems and domestic climate and energy policies would: encourage the early identification of problem areas needing extra attention, highlight effective "concessions" to reach agreement, and help locate ambitious member states willing to heavily accommodate in order to reach an ambitious agreement.

The first half of the ACF's expectation, that the 2030 Framework may be understood as a compromise among different advocacy coalitions, was only supported under three conditions: a) coalitions included key stakeholders such as member state governments and the Commission, b) coalitions consisted of stakeholders holding comparatively similar positions, and c) stakeholders coordinated behavior in at least a minimal sense (e.g. shared information and/or adjusted their strategies to each other, regarded as weak forms of coordination in Sabatier's terminology). In European Council negotiations, which were decisive, it is pertinent to view member state governments as independent entities, and not just actors being used by industrial or other stakeholders. Therefore, 
analyses of European Council negotiation outcomes should include the member state governments' positions and actions. However, as these governments seldom or never publish press releases, organize joint events, or otherwise hold collective activities with non-public stakeholders, private and public stakeholders may not demonstrate "strong coordination" in Sabatier's terminology. Therefore, the eventual cooperation and coordination between member state governments and advocacy coalitions must be based on information sharing or coordination. Even when these public-private coalitions likely exist, identifying such grand overarching coalitions is impeded by poor access to data, specifically documentation of long-term information sharing to influence policy development among interest group representatives, journalists, agency officials and politicians at multiple governmental levels. Therefore, Sabatier (1998) seems to have underestimated the methodological difficulties in applying the ACF to EU-level processes.

The second half of the ACF's expectation was met: the ACF has, in this context, proven useful for identifying and explaining advocacy coalitions in the interest group community. The data demonstrates that the interest group system in the EU not only consists of ad hoc issue-specific coalitions, as argued by Mahoney (2007:366) and Rozbicka (2013: 847), but also long-term advocacy coalitions, even under strict and narrow operationalization. Such long-term advocacy coalitions in the EU interest group community should be a topic for future research. The study identified three multilevel advocacy coalitions which shared political views in climate and energy issues, and cooperated and coordinated non-trivially over long periods of time: a) the utilities industry; b) the "Broad Green Community," featuring the renewables industry, businesses and other industries relating to energy efficiency (e.g. the construction sector), environmental organizations, and think tanks; and c) the AEII (Alliance of the Energy Intensive Industries). Analysis of these advocacy coalitions' rhetoric shows that these coalitions are unified in viewing action on climate change as crucial, but they radically disagree on the means to this target. For practitioners, knowing that these advocacy coalitions exist and how they argue may expedite the understanding of stakeholder positions, as each advocacy coalition's presented views are fairly representative of their members.

HI has contributed to documenting how the EU's key supranational institutions have, over time, attained greater legislative competence in a field characterized by national sovereignty, and how ideas, such as the importance of overarching climate and energy targets, have persisted (ideational path dependency). The Commission played agenda setter in the formulation of the 2030 Framework, as expected. However, HI does not explain the Parliament's 
seemingly minor role in influencing the 2030 Framework, despite its strong commitment. Although the Parliament generally has strong powers in EU decision making, this authority does not necessarily translate into influencing the European Council's decisions regarding the EU's climate and energy frameworks.

LI and HI are not necessarily contradictory, as demonstrated in this analysis. Pierson (1996:157) commented that HI may fill "the gap" in the LI of Moravcsik (1993) by shedding light on how long-term political processes lead national governments to gradually lose control over decisions which affect them. This complementary relationship is exemplified in the 2030 Framework negotiations: LI has proved appropriate for analyzing important aspects of governmental bargaining, while $\mathrm{HI}$ has helped document the processes of long-term transfer of legislative competence to the EU level in climate and energy policy. Schimmelfennig (2015:99) underlines a crucial difference between the two theoretical perspectives, that interdependence in LI is exogenous, while interdependence is endogenous to EU integration in HI. Therefore, the negotiations and ensuing 2030 Framework can be viewed as a result of both exogenous and endogenous member state interdependence.

Under certain conditions, the ACF may be integrated with the other theoretical perspectives. The perspectives share some concepts, like that the individual has bounded rationality (Simon 1976) and that analyses may include agents as well as structures. The ACF and HI are similar in their emphasis on long-term political processes and on factors that might change a governmental system. However, if the advocacy coalitions are the "real" agents in various EU policy spheres, then the stakeholders highlighted by LI and HI must be less important. This points towards a further challenge in applying the ACF: when all participants in a policy field, including governmental representatives, are theoretically members of an advocacy coalition, it becomes unclear as to which decision makers advocacy coalitions are lobbying.

\section{References}

Alliance of the Energy Intensive Industries (2013a). Carbon leakage protection for EU industry is under threat. Urgent call to safeguard Europe's industrial competitiveness. September 30 .

Alliance of the Energy Intensive Industries (2013b). Position of the Alliance of Energy Intensive Industries on the Commission proposal to back-load (set-aside) EU ETS allowances. August 6. 
Alliance of the Energy Intensive Industries (2014). The 2030 climate and energy framework must guarantee predictability for industry by setting the principles for measures against carbon and investment leakage now. September 4.

Bennett, A. and J. T. Checkel, editors (2015). Process Tracing: From Metaphor to Analytic Tool. Cambridge: Cambridge University Press.

Benson, D. and D. Russel (2014). "Patterns of EU Energy Policy Outputs: Incrementalism or Punctuated Equilibrium?" West European Politics 38, 1: 185-205.

Boasson, E. L. and J. Wettestad (2013). EU Climate Policy: Industry, Policy Interaction and External Environment. Farnham: Ashgate.

BP (2013). Consultation response to the European Commission's Green Paper on a 2030 framework for climate and energy policies. Brussels.

Braun, Mats (2014). "EU Climate Norms in East-Central Europe." JMcs: Journal of Common Market Studies 52, 3: 445-46o.

Bundesverband Erneuerbare Energie (2014). Barroso gibt Europas Schrittmacher-Rolle auf [Press release]. January 22.

Bürgin, Alexander (2014). "National Binding Renewable Energy Targets for 2020, but not for 2030 anymore: Why the European Commission Developed from a Supporter to a Brakeman." Journal of European Public Policy 55, 5: 690-707.

Burns, C., N. Carter, G. A. M. Davies, and N. Worsfold (2013). "Still saving the earth? The European Parliament's Environmental Record." Environmental Politics 22, 6: 935-954.

Capoccia, G. and D. R. Kelemen (2007). "The Study of Critical Junctures: Theory, Narrative, and Counterfactuals in Historical Institutionalism." World Politics 59, 3: 341-369.

Casinge, Ekaterina (2014). "Green MEP: Lobbyists Stopped Ambitious EU Energy Targets." Euractiv, November 7. At: http://www.euractiv.com/sections/energy/green -mep-lobbyists-stopped-ambitious-eu-energy-targets-309867.

Climate Action Network Europe (2015). Members. At: http://www.caneurope.org/ member-directory?force $=1$.

Coalition of Progressive European Energy Companies (2012). Coalition of energy companies calls for a binding EU 2030 renewables framework. EU Energy Ministers should support a strong ETS and renewables targets [Press release]. June 5 .

Confederation of British Industries (2013). A Smart EU Energy and Climate Change Policy Framework can be a Source of Jobs and Growth in Europe. London.

Confederation of European Business (2013). A Competitive EU Energy and Climate Policy: BusinessEurope Recommendations for a 2030 Framework for Energy and Climate Policies. Brussels. At: https://www.businesseurope.eu/sites/buseur/files/ media/imported/2013-0o699-E.pdf.

Council of the European Union (2007). Presidency conclusions. Brussels Council 8 and 9 March 2007. 7224/1/07, May 2. Brussels. 
Council of the European Union (2014a). Communication from the Commission on "A policy framework for climate and energy in the period from 2020 to 2030," replies received from Belgium, Germany, Portugal and Sweden to the Presidency questions. June 11. Brussels.

Council of the European Union (2014b). Communication from the Commission on "A policy framework for climate and energy in the period from 2020 to 2030," replies received from the Czech Republic and the Netherlands to the Presidency questions. June 11. Brussels.

Council of the European Union (2014c). Communication from the Commission on "A policy framework for climate and energy in the period from 2020 to 2030," replies received from the United Kingdom to the Presidency questions. March 3. Brussels.

Council of the European Union (2014d). Conclusions on 2030 Climate and Energy Policy Framework. SN 79/14, October 23. Brussels.

Council of the European Union (2014e). European Council (23 and 24 October 2014) Draft conclusions. 12782/14, October 13. Brussels.

Crisp, James (2014). "Electricity linkage target dropped ahead of EU summit." Euractiv, October 23. At: http://www.euractiv.com/sections/energy/electricity-linkage-target -dropped-ahead-eu-summit-309410.

Darby, Megan (2014a). "Danish minister tours Europe to promote 2030 climate deal." Climate Home, October 10. At: http://www.climatechangenews.com/2014/10/10/dan ish-minister-tours-europe-to-promote-203o-climate-deal/.

Darby, Megan (2014b). "Poland isolated as pressure mounts on EU to deliver 2030 climate deal." Climate Home, October 22. At: http://www.climatechangenews.com/2014/10/ 22/poland-isolated-as-pressure-mounts-on-eu-to-deliver-2030-climate-deal/.

Davey, Edward (2013). Ambitious and Flexible - Europe's 2030 Framework for Emissions Reduction [Speech]. London: UK Government, Department of Energy and Climate Change.

Der Spiegel (2014). “Grünen-Fraktionschef: Hofreiter wirft EU Verrat an Klimaschutz vor." October 24. At: http://www.spiegel.de/politik/ausland/gruenen-fraktionschefhofreiter-wirft-eu-verrat-an-klimaschutz-vor-a-999045.html.

Die Zeit (2014). "EU-Gipfel einigt sich auf Klimaschutz-Paket." October 24. At: http:// www.zeit.de/politik/2014-10/klimaziele-eu-gipfel.

Dür, Andreas (2008). "Measuring Interest Group Influence in the EU: A Note on Methodology." European Union Politics 9, 4: 559-576.

Eckstein, Harry (1975). "Case study and theory in political science," in F. I. Greenstein and N. W. Polsby, editors, Handbook of Political Science. Reading, MA: Addison-Wesley.

Egeberg, Morten (2012). "Experiments in supranational institution-building: the European Commission as a laboratory." Journal of European Public Policy 19, 6: 939-950.

Energy UK (2013). Energy UK response to EU Green Paper on a 2030 Framework for Climate and Energy Policies. London. 
EUfOres (2013). A binding Future for 2030 RES Target? A 2030 Package Discussion. At: http://www.eufores.org/index.php?id=210.

EurActiv (2014). Member states' positions on EU 2030 climate targets. October 17. At: http://cf.datawrapper.de/kbpOX/2/.

European Association for Coal and Lignite (2013). EURACOAL Response to Public Consultations on the Green Paper - A 2030 framework for climate and energy policies and on the Future of Carbon Capture and Storage in Europe. Brussels.

European Commission (2013a). Green paper. A 2030 framework for climate and energy policies. сом(2013) 169 final, March 27. Brussels.

European Commission (2013b). Green Paper 2030: Main outcomes of the public consultation. Commission Services Non Paper. Brussels.

European Commission (2014a). A policy framework for climate and energy in the period from 2020 to 2030. $\mathrm{COM(2014)} 15$ final, January 22. Brussels.

European Commission (2014b). Energy Efficiency and its contribution to energy security and the 2030 Framework for climate and energy policy. Сом(2014) 520 final, July 23. Brussels.

European Commission (2014c). European Energy Security Strategy. $\operatorname{com(2014)~} 330$ final, May 28. Brussels.

European Environmental Bureau (2013). The E EB's response to the European Commission's Consultation on a 2030 framework for climate and energy policies. Brussels.

European Renewable Energy Federation (2013). EREF's reply to the European Commission Green paper on 2030 Climate and Energy Framework. Brussels.

European Trade Union Confederation (2014). No Jobs on a Dead Planet [Press release]. October 20. Brussels.

Eurostat (2015a). National accounts and GDP. At: http://ec.europa.eu/eurostat/statistics -explained/index.php/National_accounts_and_GDP.

Eurostat (2015b). Population on ı January. At: http://ec.europa.eu/eurostat/tgm/refresh TableAction. do $?$ tab $=$ table $\&$ plugin $=1 \&$ pcode $=$ tpsoooo $\&$ language $=e n$.

Evans, Simon (2014). "How self-interest is framing the EU 2030 climate debate." Climate Spectator, October 17. At: http://www.businessspectator.com.au/article/2014/10/21/ policy-politics/how-self-interest-framing-eu-2030-climate-debate.

Fagan-Watson, B., B. Elliott, and T. Watson (2015). Lobbying by Trade Associations on EU Climate Policy. London: Policy Studies Institute.

Fischer, Severin (2014). "The EU's New Energy and Climate Policy Framework for 2030." swP Comments. Berlin: German Institute for International and Security Affairs.

Flynn, Valerie (2014). "Seven countries back binding EU efficiency goal." ENDS Europe, June 18. At: http://www.endseurope.com/article/36216/seven-countries-back-binding -eu-efficiency-goal.

Friedrich, Carl J. (1941). Constitutional Government and Democracy: Theory and Practice in Europe and America. Boston: Little, Brown, and Co. 
Friends of the Earth(2014). "EU 2030 climate plan disregards science." Friends of the Earth Europe, January 22. At: http://www.foeeurope.org/2030_climate_energy_plan_220114.

Gas Infrastructure Europe (2013). GIE answer to European Commission's consultation on the Green Paper "A 2030 framework for climate and energy policies." Brussels.

Gotev, Georgi (2014). "Poland says it 'won' at the EU summit." Euractiv, October 24. At: http://www.euractiv.com/sections/energy/poland-says-it-won-eu-summit-309494.

Green Budget Europe (2013). Public consultation "Green Paper on a 2030 framework for climate and energy policies." Brussels.

Green Growth Group (2013). Going for Green Growth: The case for ambitious and immediate EU low carbon action. London.

Green Growth Group (2014). Green Growth Group Ministers' statement on climate and energy framework for 2030. London: UK Department of Energy and Climate Change.

Greenpeace EU (2014). Tied Down: Why Europe's Energy Giants Want to Keep Us Hooked on Imported Fossil Fuel. Brussels.

Hix, S. and B. Høyland (2013). "Empowerment of the European Parliament." Annual Review of Political Science 16: 171-189.

Ibec (2013). Summary of Member State responses to the 2030 green paper for a climate and energy framework. At: http://www.ibec.ie/IBEc/DFB.nsf/vPages/Energy Re sources $\sim$ summary-of-member-state-responses-to-the-203o-framework-on-14 -10-2013/\$file/Member+State+responses+to+2030+green+paper.pdf.

Institutional Investors Group on Climate Change (2013). Response to public consultation on Green Paper on a 2030 framework for climate and energy policies. London.

International Association of Oil \& Gas Producers (2013). OGP Response to the Green Paper "A 2030 framework for climate and energy policies." Brussels.

Jenkins-Smith, H. C., D. Nohrstedt, C. M. Weible, and P. A. Sabatier (2014). "The Advocacy Coalition Framework," in P. A. Sabatier and C. M. Weible, editors, Theories of the Policy Process. Boulder, CO: Westview Press.

Jupille, J., J. A. Caporaso, and J. T. Checkel (2003). "Integrating Institutions: Rationalism, Constructivism, and the Study of the European Union." Comparative Political Studies 36, 1-2: 7-40.

Keating, Dave (2014). "Merkel casts doubt on climate agreement." EuropeanVoice, October 17. At: http://www.europeanvoice.com/article/merkel-casts-doubt-on-cli mate-agreement/.

Kopeinig, Margaretha (2014). "Österreich soll wieder "Umwelt-Vorreiter" werden." Kurier, March 31. At: https://kurier.at/politik/inland/oesterreich-soll-wieder-umwelt -vorreiter-werden/58.356.505.

Krasner, Stephen D. (1984). "Approaches to the State: Alternative Conceptions and Historical Dynamics." Comparative Politics 16, 2: 223-246.

Lidegaard, Martin (2013). Green Paper on a 2030 Framework for climate and energy policies [Letter]. June 28. Copenhagen: Danish Ministry of Climate, Energy and Building. 
Magritte Group (2014a). First reactions of the Magritte Group of CEOs on the package relating to the energy and climate framework towards 2030 published today by the European Commission [Press release]. January 22. Brussels.

Magritte Group (2014b). Magritte Group calls for immediate and drastic measures to safeguard Europe's energy future [Press release]. March 19. At: https://www.gdfsuez .com/wp-content/uploads/2014/03/magritte-group-call-for-immediate-and-drastic -measures-to-safeguard-europe-s-energy-future-march-19th-2014.pdf.

Mahoney, Christine (2007). "Networking vs. allying: the decision of interest groups to join coalitions in the US and the EU." Journal of European Public Policy 14, 3: 366-383.

Mitterlehner, Reinhold et al. (2013). Call for a renewable energy target in EU's 2030 climate and energy framework [Letter]. December 23.

Moravcsik, Andrew (1993). "Preferences and Power in the European Community: A Liberal Intergovernmentalist Approach." JMCs:Journal of Common Market Studies 31, 4: 473-524.

Moravcsik, Andrew (1998). The Choice for Europe: Social Purpose and State Power from Messina to Maastricht. Ithaca, NY: Cornell University Press.

Moravcsik, A. and F. Schimmelfennig (2009). "Liberal Intergovernmentalism," in A. Wiener and T. Diez, editors, European Integration Theory. Oxford: Oxford University Press.

Mouvement des Enterprises de France, Bundesverband Deutsche Industrie and Lewiatan (2014). The Sopot Recommendations. The Weimar Triangle Business Message to the New European Institutions. Sopot, Mouvement des Enterprises de France, Bundesverband Deutsche Industrie and Lewiatan.

Neslen, Arthur (2014). "EU leaders agree to cut greenhouse gas emissions by $40 \%$ by 2030." The Guardian, October 24. At: http://www.theguardian.com/world/2014/ oct/24/eu-leaders-agree-to-cut-greenhouse-gas-emissions-by-40-by-203o.

Neslen, Arthur (2015). "Shell lobbied to undermine EU renewables targets, documents reveal." The Guardian, April 27. At: http://www.theguardian.com/environment/2015 /apr/27/shell-lobbied-to-undermine-eu-renewables-targets-documents-reveal ?CMP=share_btn_tw.

Newmark, A. J. and A. J. Nownes (2017). "It's all relative: Perceptions of interest group influence." Interest Groups \& Advocacy 6, 1: 66-9o.

Parliament (2014a). Report on a 2030 framework for climate and energy policies (2013/2135(INI)). European Parliament: Committee on the Environment, Public Health and Food Safety, Committee on Industry, Research and Energy.

Parliament (2014b). Texts Adopted Part III at the sitting of Wednesday 5 February 2014. Strasbourg.

Pierson, Paul (1996). "The Path to European Integration: A Historical Institutionalist Analysis." Comparative Political Studies 29, 2: 123-163. 
Pierson, Paul (2000). "The Limits of Design: Explaining Institutional Origins and Change." Governance 13, 4: 475-499.

Polski Komitet Energii Electrycznej (2014). Impact assessment of the EC climate and energy policy proposal for years 2020-2030 on Poland: Synthesis. Warsaw.

Romson, Åsa (2014). Uttalande från klimat- och miljöminister Åsa Romson angående regeringens position inför beslut om EU:s klimat- och energiramverk. Stockholm: Regeringskanseliet.

Rozbicka, Patrycja (2013). "Advocacy coalitions: influencing the policy process in the EU." Journal of European Public Policy 20, 6: 838-853.

Sabatier, Paul A. (1988). "An Advocacy Coalition Framework of Policy Change and the Role of Policy-Oriented Learning Therein." Policy Sciences 21, 2/3:129-168.

Sabatier, Paul A. (1998). "The advocacy coalition framework: revisions and relevance for Europe." Journal of European Public Policy 5, 1: 98-130.

Sabatier, P. A., S. Hunter, and S. McLaughlin (1987). "The Devil Shift: Perceptions and Misperceptions of Opponents." The Western Political Quarterly 40, 3: 449-476.

Sattich, Thomas (2013). Neue Akteure - Neue Policy? Die Folgen die EU Erweiterung von 2004 und 2007 für die europäische Governance-Prozesse: Ein Fallstudie auf dem Gebiet der europäischen Klima- und Energiepolitik [PhD dissertation]. University of Bremen: The Research Centre for East European Studies.

Schimmelfennig, Frank (2015). "Efficient process tracing. Analyzing the causal mechanisms of European integration," in A. Bennett and J. T. Checkel, editors, Process Tracing: From Metaphor to Analytic Tool. Cambridge: Cambridge University Press.

Simon, Herbert A. (1976). Administrative Behavior: A Study of Decision-making Processes in Administrative Organization. New York: Free Press.

Skjærseth, J. B., P. O. Eikeland, L. H. Gulbrandsen and T. Jevnaker (2016). Linking EU Climate and Energy Policies: Decision-making, Implementation and Reform. Cheltenham: Edward Elgar.

Süddeutsche Zeitung 2014. "Europa will Führungsrolle beim Klimaschutz." October 24. At: http://www.sueddeutsche.de/news/politik/eu-europa-will-fuehrungsrolle-beim -klimaschutz-dpa.urn-newsml-dpa-com-20090101-141024-99-00710.

Tallberg, Jonas (2008). "Bargaining Power in the European Council." JCMs: Journal of Common Market Studies 46, 3: 685-708.

Tallberg, Jonas (2010). "Explaining the institutional foundations of European Union negotiations." Journal of European Public Policy 17, 5: 633-647.

The Coalition for Energy Savings, European Renewable Energy Council and Climate Action Network Europe (2013a). Joint call for mutually reinforcing and binding energy savings, renewable energy and greenhouse gas reduction targets [Letter]. April 19. The Coalition for Energy Savings (2013b). Priority for renewable energy and energy efficiency needed to respond to crisis [Letter]. May 17. 
The Coalition for Energy Savings (2013c). Subject: Impact assessment for the 2030 climate and energy framework [Letter]. November 21.

The European Atomic Forum (2013). A 2030 Framework for climate and energy policies. The view of Europe's nuclear energy industry. Brussels.

The European Union of the Natural Gas Industry (2013). Eurogas Response to the European Commission's 2030 Energy and Climate Package. Brussels.

The Prince of Wales's Corporate Leaders Group (2014). Leading Businesses Urge Europe to Agree Ambitious Climate and Energy Policies this Week [Press release]. October 5 .

Thomson, Robert (2011). Resolving Controversy in the European Union: Legislative Decision-making before and after Enlargement. Cambridge: Cambridge University Press.

Tosun, J., S. Biesenbender, and K. Schulze (2015). "Building the EU's Energy Policy Agenda: An Introduction," in J. Tosun, S. Biesenbender and K. Schulze, editors, Energy Policy Making in the EU: Building the Agenda. London: Springer.

Traynor, I. and A. Neslen (2014). "EU leaders set to strike climate deal to cut greenhouse gases $40 \%$ by 2030." The Guardian, October 23. At: http://www.theguardian.com/ environment/2014/oct/23/eu-climate-deal-cut-greenhouse-gas-40-per-cent-2030.

Uken, Marlies (2014). "Kein Klimagipfel - ein Kohlegipfel." Die Zeit, October 24. At: http://www.zeit.de/politik/ausland/2014-10/eu-gipfel-kohle-polen.

Union of the Electricity Industry (2013). Cleaner, simpler, smarter: cost-efficient energy for Europe's business and consumers: Green Paper on a 2030 framework for climate and energy policies. Brussels.

Union of the Electricity Industry (2014). European electricity industry views ahead of the European Council of October 2014 [Letter]. September 17. Brussels.

Union of the Electricity Industry, IndustriAll European Trade Union and European Public Service Union (2013). Joint EURELECTRIC/IndustriAll/EPSU position on the 2030 Framework for Climate and Energy Policies. Brussels.

Visegrad Group (2014a). Joint Statement of the 2oth Meeting of the Ministers of Environment of the Visegrád Group Countries, Bulgaria, Republic of Croatia and Romania. May 8.

Visegrad Group (2014b). Joint Statement of the 21st Meeting of the Ministers of Environment of the Visegrad Group Countries, the Republic of Bulgaria and Romania. September 30. Bratislava.

Visegrad Group (2014c). Joint Statement of the informal meeting of ministers and representatives responsible for climate policy of the Visegrad Group Countries, Bulgaria and Romania. February 7. Budapest.

Weible, C. M., P. A. Sabatier and K. McQueen (2009). "Themes and variations: Taking stock of the advocacy coalition framework." Policy Studies Journal 37, 1: 121-139.

Wettestad, J., P. O. Eikeland and M. Nilsson (2012). "EU Climate and Energy Policy: A Hesitant Supranational Turn?" Global Environmental Politics 12, 2: 67-86. 
Yin, Robert K. (2009). Case Study Research: Design and Methods. Thousand Oaks, CA: Sage.

Ydersbond, Inga Margrete (2012). Multi-level lobbying in the EU: the case of the Renewables Directive and the German energy industry. FNI Report 10/2012. Lysaker: Fridtjof Nansen Institute.

Ydersbond, Inga Margrete (2014). "Multilevel 'venue shopping': The case of EU's Renewables Directive." Interest Groups \& Advocacy 3, 1: 30-58.

Ydersbond, Inga Margrete (2016). Where is the power really situated in the EU? The case of multi-stakeholder complex negotiations and the climate and energy 2030 targets. FNI Report 3/2016. Lysaker: Fridtjof Nansen Institute.

Zafonte, M. and P. A. Sabatier (1998). "Shared Beliefs and Imposed Interdependencies as Determinants of Ally Networks in Overlapping Subsystems." Journal of Theoretical Politics 10, 4: 473-505. 